https://doi.org/10.18485/cosic_dobrica.2018.ch2

821.163.41:929 Ћосић Д.

821.163.41.09-94 Ћосић Д.

94(497.1)"19/20"

\author{
ЈЕЛЕНА Ј. ГУСКОВА* \\ Институт за славистику РАН, Москва
}

\title{
ЗНАЧАЈ ДЕЛАТНОСТИ ДОБРИЦЕ ЋОСИЋА ЗА ИСТОРИЈСКА ИСТРАЖИВАҢА ПОСЛЕРАТНЕ ИСТОРИЈЕ ЈУГОСЛАВИЈЕ
}

\begin{abstract}
Наслеђе Добрице Ћосића је врло важно за историчаре. У овим свакодневним записима, којима се бавио током читавог живота, Ћосић је писао о ставовима њему блиских људи из политичког и јавног живота, смештајући их у контекст друштвеног живота целе земље. При томе, основно правило, од кога он није одустајао, било је следеће: народу и историји потребна је само истина, само правда и слобода. Његови дневници су били „лична историја једног доба”. Ово је полувековна историја земље у којој је живео, коју ће историчари, захваљујући Ћосићу, сада лакше разумети.
\end{abstract}

Кључни речи: Добрица Ћосић, дневници, Југославија, историја, Косово и Метохија.

Основни подаци о великом српском писцу Добрици Ћосићу могу се наћи у бројним енциклопедијама, публикованим од друге половине XX века. У време постојања ФНРЈ, у енциклопедијском издању из 1956. године, објављеном у Загребу, написано је „да је он аутор и учесник НОРa" и да „активно учествује у политичком животу земље” (Enciklopedija 1956: 205). У енциклопедији из 1984. године, Ћосићу је посвећено много више простора. Написано је да је Ћосић књижевник - писац и човек на различитим 'културно-политичким дужностима' (Enciklopedija Jugoslavije 1984: 346-347). Савремени интернет приручници карактеришу га као српског писца, политичара и теоретичара српског националног покрета (Википедия.рф.s.a.). Поједини руски и српски сајтови (2010) именују га 'легендарним српским романописцем и есејистом, националним и политичким теоретичаром', а често га називају 'оцем српске нације' (Добрица Чосич Веб. 24. 5. 2010). Многе његове написане или изговорене мисли се и данас цитирају као део широко прихваћених ставова о судбини српског народа. Једна од таквих је, на пример, и она да је „српски народ добијао у рату, а губио у миру”.

*jelenaguskova@gmail.com 
Величина и значај овог човека у југословенској и српској политичкој историји и књижевности још увек није у потпуности сагледана. Чини ми се да са разговорима на нашем данашњем научном скупу тек почињемо да радимо на формулисању објективних, научно утемељених, оцена о њему. Добрица Ћосић је живео у веома занимљивом времену. Он је рођен и одрастао у Краљевини Југославији, борио се против фашизма, живео је у ФНРЈ, СФРЈ, СРЈ, СЦГ, Србији. Он је био сведок краха јаке федерације, каква је била СФРЈ, а деведесетих година XX века, као њен председник, покушавао је да спасе Савезну Републику Југославију (државну заједницу Србије и Црне Горе). И на крају, он је био сведок потпуног слома идеје југословенства.

Далеке 1997. године записала сам (и нисам објавила) разговор са Добрицом Ћосићем. Сада могу то да урадим, јер писац даје оцене свог рада и живота. Тада је о свом времену рекао:

За мене, савременика, XX век је имао само седам деценија и трајао је од 1914. до 1990. године. Био је тај век - звер! У ових седам деценија, убијено је више људи него за претходних седам векова и произведено толико смртоносне енергије да наша планета може да пукне као лубеница и да се спали у пепео као колиба. Промене су биле епохалне и прошле су изузетним темпом. Историја као олуја газила је људске судбине, народе и цело човечанство. У нашем веку људи су долетели до Месеца и Марса и данас је на земљи свако место видљиво и прислушкивано и не постоји место где човек не може да не стигне у исти дан, а око нас и у нама самима широко су се населиле рушевине људских идеја и креација. А од тог материјала не изградиш мирну будућност. Ја више не препознајем људска лица и не знам шта је сада мој народ, на који је сишла тама историје.

О нашем веку без ризика може се говорити само кад је реч о политичким реалностима. Због тога ћу и ја искористити ову прилику. Уопштено говорећи, сматрам да је стварање Америке као велике силе и њена трансформација у светског владара крајем века истовремено са колапсом Совјетског Савеза и катастрофалним уништењем Русије као светске силе најзначајнији историјски догађај у двадесетом веку. Такође, треба сматрати великим догађајима уништавање марксистичко-бољшевистичке идеологије као најјаче друштвене есхатологије нове светске историје и истовремено ширење америчког империјализма као 'новог светског поретка' у идеологију људских права, коју прати јако, неодољиво ширење ислама, нове моћне политичке религије. Настанак Европске Уније под доминацијом велике Немачке прекретница је у историји Европе са веома нејасним последицама. Потребно је рећи и то да у двадесетом веку нове технологије стварају нову цивилизацију, која се манифестује као одлучујући, иако још увек несамостални фактор развоја. У очекивању развоја, утицаја и значаја технолошког фактора за будућност планете сви данашњи пророци глупи су и слепи (Ћосић 1997). 
Што је најважније: Добрица Ћосић није био само писац који је посматрао свет из академског мира свог радног кабинета. Напротив, потреба да активно учествује у друштвеним процесима, заснована на осећању части и личне одговорности за судбину свога народа, стално га је гурала у средиште догађаја, где је обављао за земљу важне политичке функције. Био је: политички комесар, уредник новина, члан Покрајинског одбора омладине Србије, дванаест година био је републички и савезни посланик, председник Српске књижевне задруге. А затим - опозиционар, учитељ и творац многих будућих вођа опозиције. Осим тога - председник државе, човек који је давао добре анализе савремених политичких догађаја.

Срећан сам као писац, јер живим заједно са својим народом у за њега несрећно и тешко време. Историја ми је давала идеје за романе, а ја сам покушао да се њој супротставим својом креативношћу и поетском меморијом. Пре свега, као револуционар сам желео да променим судбину свог трагичног народа, али 'Велики Механизам' историје победио ме је у постизању мог циља. Мој пораз, односно пораз револуционарних идеала на југословенској земљи схватио сам скоро три деценије раније него што се он у потпуности манифестовао у нашем животу и постао сам критичар и активан противник режима Тита (Ћосић 1997).

Зашто је наслеђе Д. Ћосића занимљиво за историчаре? Одговор се може наћи у властитим речима великог писца. Он је, схватајући значај мемоарских записа за будуће истраживаче било ког периода историје, говорио: „Опиши и остави суду историје” (Ћосић 2008: 8). У овим свакодневним записима, којима се бавио током читавог живота, Ћосић је писао о ставовима њему блиских људи из политичког и јавног живота, смештајући их у контекст друштвеног живота целе земље. При томе, основно правило, од кога он није одустајао, било је следеће: народу и историји потребна је само истина, само правда и слобода. Када читате дневнике и записе Добрице Ћосића, не напушта вас осећај велике искрености аутора, његове бриге да потомцима остави детаљне податке о збивањима, које је забележио частан човек. Врло су важне његове оцене збивања 90-их година.

У развоју и судбини балканских народа данас се дешавају промене супротне главним правцима развоја у Европи, које су карактеристичне за недовољно развијене нације. Губитком бољшевистичког социјализма и распадом Југославије, разбијени на дијаспоре балкански народи стварају независне националне државе. Овај процес је пратио међунационални, верски и грађански рат. Распад Југославије, који је подржала Немачка објашњавајући ту чињеницу њеним интересима, као и интересима ЕУ и стратешким интересима Америке, донео је несагледиву беду неким на- 
родима, а највише српском. Реч је о стварању нових националних држава на Балкану под протекторатом Америке и Европске Уније, о ултиматуму српском народу, о увођењу санкција против Савезне Републике Југославије, о војној интервенцији у Републици Српској и окупацији Босне и Херцеговине НАТО-ом, о забрани српском народу да користи иста права која имају Хрвати, Словенци и Македонци. Балкан је крајем двадесетог века поново постао 'јабука раздора' и 'буре барута'. Убеђен сам да ће неминовно доћи до решења преосталих незавршених историјских процеса: стварање јединствене државе српског народа, уједињење албанског народа у независној националној држави и миран завршетак поделе Босне и Херцеговине по етничком принципу на основу права народа на самоопредељење. Окупацијом, санкцијама и насиљем очување неке 'заједничке државе Босне и Херцеговине' сматрам неразумном, ризичном и регресивном акцијом 'међународне заједнице', тј. водећих снага - Америке и Немачке. Док траје окупација НАТО-а, дејтонска држава Босна и Херцеговина ће постојати. Од катастрофе народе Босне и Херцеговине може спасити само мирно, територијално и политичко разграничење, које не би требало да се оваплоти у етнички чисте територије. Овај тежак задатак може да се спроведе без рата, само уз директно учешће ЕУ, Америке и Русије, који су својом политиком изазвали и учинили могућим страшни грађански рат у Босни и Херцеговини (Ћосић 1997).

Добрица Ћосић је писао свој дневник од 1951. до 2000. године. Ово је полувековна историја земље у којој је живео, коју ће историчари, захваљујући Ћосићу, сада лакше разумети. Дневници су пуни искрености. Њих је писао човек који се идентификовао са временом у коме је живео. Његови дневници су били „лична историја једног доба”. Он је писао о „својој и српској садашњости као њена мислећа, осетљива, неспокојна честица, као савременик судбоносних друштвених, идеолошких и духовних збивања у Југославији која је била држава и српског народа; као сведок, а у неким опозиционим и дисидентским догађањима и као њихов покретач" (Ћосић 2009a: VII). Збивања у Југославији и српском народу у другој половини XX века виђена су очима писца и описивана језиком писца. Ћосић се релативно рано „сукобио са самим собом”, са својим идејама, идеалима и стварношћу реалног друштва и човека. Брзо је схватио свој идеолошки романтизам и борбени песимизам, кад је проживљавао драму Милована Ђиласа 1954, кад је сазнао за Кардељево антијугословенство 1957, кад је видео Тита на путу у Африку 1962. као „стаљинистичког и аустроугарског аутократу”. Тада је прешао „на другу обалу".

А сада замислите да неки историчар у будућности пише о 'Другој Југославији' и да има само документе КПЈ-СКЈ. Необјективност би, таквим приступом, била гарантована! Због тога је „сведочење о тој епохи” 
у књигама Ћосића „са друге обале” драгоцен материјал и за историчаре. Историчару су врло важне чињенице. А ми знамо да је у томе Ћосић био непогрешив.

Дакле, када се данас пише о Јосипу Брозу Титу, Јосифу Висарионовичу Стаљину, о совјетско-југословенским односима, о Александру Ранковићу, Миловану Ђиласу, студентском покрету из 1968. године, албанском питању, политици несврстаних, распаду Југославије итд., све до агресије НАТО-а 1999. године, без радова Добрице Ћосића сви ти догађаји и збивања не могу се у потпуности разумети. Сам писац тако оцењује своју делатност.

Посветио сам своје време углавном проналажењу истине о људској судбини на српским земљама у 20. веку поетским средствима и уз помоћ маште, описујући своје разумевање у романима „Време смрти”, „Време зла” и „Време власти”. Када је 1992. године српски народ био сломљен, на ивици пропасти и под међународним санкцијама, када су га међународни владари поставили у положај парија и светског криминалца, преузео сам дужност председника Савезне Републике Југославије са циљем да послужим спасењу Србије и Црне Горе од историјске катастрофе. Са мојим политичким концептима и циљевима нису били сагласни људи који су имали јаке политичке партије и моћ у парламенту и по истеку године после мог избора скинули су ме са позиције председника Савезне Републике Југославије, оптужујући ме да сам „прекршио Устав". Нисам ништа предузео против ове оставке. Са миром у срцу, са мирном савешћу и са радошћу вратио сам се свом занату и проблемима грађанских слобода (Ћосић 1997).

Питања која су посебно занимала писца тицала су се судбине Србије и српског народа, Косова и Метохије. Ова питања, којима је посветио неколико књига, била су за Ћосића веома „важна и болна”.

Крајем 60-их Добрица Ћосић је први говорио о националној политици СКЈ на Косову и Метохији, о албанском агресивном национализму, о расту антисрпског расположења у том крају. Зар би историчари знали о правом стању ствари на КиМ без његових књига? Давне 1968. године, говорио је Ћосић на пленуму ЦК СК Србије отворено о тешкоћама у међунационалним односима у земљи, о проблемима на Косову. Први пут се чула реч о нетолеранцији, себичности, па чак и мржњи која постоји између два народа, српског и албанског. Писац је критиковао и српски национализам и „етноцентричну енергију” Албанаца, њихову „жељу да се уједине са својом браћом у Албанији”. Он није веровао да идеји „братства и јединства” може бити супротстављена идеја стварања јединствене албанске државе, јер би се у том случају појавио проблем са границама (Ћосић 1998: 28, 31). Тада је на седници ЦК СК Србије, 
на којој је наступио, од стране својих партијских колега био осуђен као 'диверзант' и 'поражена снага која дезавуише политику Савеза комуниста' (Исто). Он је покушао не само да скрене политичку пажњу државног врха на проблеме у овој аутономној покрајини него и да понуди решења. Очекујући велику политичку кризу и тешке последице борбе Албанаца за отцепљење, он је разрадио план поделе Косова на српски и албански део. Чак је на мапи Покрајине и означио границе, покушавајући да у српски део укључи српску етничку већину, споменике српске културе - српске православне цркве и манастире, којима је тако богато Косово. Таква идеја није наишла на подршку код руководства земље, а Ћосић је био оштро критикован од стране партијских другова. Да је тада било слуха за оно што је говорио прави патриота, данас се не би цртале границе између Србије и Косова и Метохије.

Косовски проблем је постао за Ћосића део ширег проблема - Србије и српског народа. Говорећи о српском националном питању у условима братства и јединства, он је урадио скоро немогуће: показао је тежак положај Срба у историји и у периоду социјализма.

Српски народ се, нажалост, и данас, на почетку XXI века, налази у истом положају, остаје раздељен и дијаспоричан, разбацан у више локалних државних ентитета, под претњом да му се и даље - после отимачине Косова и Метохије - редукују етнички, културни и политички простор (Инђић, рукопис: 135).

Ћосић је отворено говорио о антисрпској природи режима, покушавао да пронађе пут изласка из кризе и развоја српског друштва. Ослонац је видео у томе што је карактерна одлика Срба - „друштвеност, свест о људској узајамности, осећање за историјски задатак и правду у свету, свест о вредностима слободе" (Исто: 137).

Као председник Југославије 1992-1993. године, Ћосић је оставио будућим генерацијама „Забелешке председника Савезне Републике Југославије". Да тих Забелешки нема, овај период би истраживали на основу других извора - докумената БиХ, Републике Српске и Србије, мемоара пензионера, говора политичара владајућих партија. А тај период је био веома тежак: још се осећао пожар у Хрватској, плануо је рат у БиХ, миротворци су се налазили у Хрватској и БиХ, западни свет је оптуживао Србе за злочине, различити мировни планови су стварани у главама међународних посредника.

Пред биографима предстоји велики посао, да напишу много више од онога што знамо о Добрици Ћосићу као човеку, али и као политичару који је хтео да спасе земљу од пропасти и уништења. И обавеза историчара је да пишу о њему као о председнику земље која је горела. Али главна ствар је већ урађена - сам председник детаљно је описао догађаје који су 
се десили током тих тешких година. Поред тога, лична неравнодушност и одговорност за судбину земље водиле су оловку Добрице Ћосића када је систематски бележио догађаје и даље, од 1994. до 2000.

Много је пророчанског у размишљањима Ћосића (пример Косова). Но, можемо да наведемо још један пример. Управо овим речима он завршава шести том својих записа. Датум - 1. јануар 2000. године. На овај дан, он је био под утиском „најсензационалније планетарне вести из Москве", када је Борис Јељцин добровољно поднео оставку на дужност председника Русије и предао власт „неком Путину”, како пише Добрица. Одмах следе две странице размишљања о будућности Русије.

Да ли ће тај Владимир Владимирович Путин, руски обавештајац, бити обновитељ руске државе и њене моћи по примеру Петра Великог, у шта ја верујем без иједног стварног разлога, да ли ће он вратити моћ и достојанство великом руском народу, у шта верујем својом романсијерском маштом? (Ћосић 2009б: 252)

А још раније, 1997. године, Добрица Ћосић је говорио да је само Русија и њен опоравак судбоносно питање за Европу и целу светску заједницу. И, како смо видели, није променио своје мишљење до краја живота.

Не верујем у демократску цивилизацију на планети и мир у њој без активног и продуктивног утицаја јаке, демократске и модерне Русије. Опоравак и јачање Русије, њен стварни повратак на политичку сцену света судбоносно је питање за Европу и целу светску заједницу. Наравно, ја не сматрам опоравак Русије у обнављању царског или стаљинистичког империјализма; напредак и моћ Русије видим у успостављању равнотеже снага и права свих народа, као и у животворном утицају велике културе и дубоке руске духовности на модерну цивилизацију, која брзо постаје антихуманом (Ћосић 1997).

О Добрици Ћосићу може се говорити дуго и много. Нама не би било довољно ни десет таквих научних конференција за разговор о свим питањима која су била важна за писца и друштвено-политичког лидера. Његова заоставштина је толико вишевекторна, а вредност његових радова за разумевање историјских догађаја модерног доба толико велика, да предлажем да скупове о Добрици Ћосићу организујете сваке године и да ова истраживачка научна манифестација буде трајна. 


\section{ИЗВОРИ И ЛИТЕРАТУРА}

Википедия.рф. Веб s.а.

Чосич, Добрица. Усиление России - суgьбоносньй войрос gля всеі̄о мира. Веб. 24. 5. 2010.

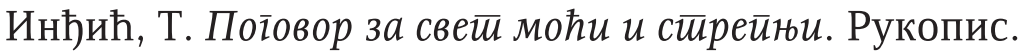

Ћосић, Добрица. Разі̄овор Јелене Гускове са Добрищом Ћосићем, 23. новембра 1997. Рукопис.

Ћосић, Добрица. Лична историја јеgної gоба. Време искушења 1951-1968. Т. 1. Београд: Службени гласник, 2009а. Шт.

Ћосић, Добрица. Лична исйорија јеgноі gоба. Време змија 1999-2000. Т. 6. Београд: Службени гласник, 2009б. Шт.

Ћосић, Добрица. „Пишчеви записи 1999-2000”. Књ. 6. Време змија. Београд: Службени гласник, 2008. Шт.

Enciklopedija Leksikografskog zavoda. T. 2. Zagreb, 1956. Št.

Enciklopedija Jugoslavije. T. 3. Zagreb: Jugoslovenski leksikografski zavod, 1984. Št.

Ćosić, Dobrica. „Govor sa sednice CK SK Serbije”. Nedeljni telegraf. Beograd, 1998. 1 apr: 28. 31. Št.

Јелена Ј. Гускова

\section{ЗНАЧАЈ ДЕЛАТНОСТИ ДОБРИЦЕ ЋОСИЋА ЗА ИСТОРИЈСКА ИСТРАЖИВАЬА ПОСЛЕРАТНЕ ИСТОРИЈЕ ЈУГОСЛАВИЈЕ}

\section{Резюме}

Наследие Д. Чосича очень важно историкам. Добрица Чосич был не только писателем, который смотрит на мир из-за своего письменного стола. Наоборот, активная жизненная позиция и честность постоянно его толкали в гущу событий, где он занимал важные для страны политические должности. И описанием каждого прожитого дня в контексте жизни всей страны и близкого политического и общественного окружения Добрица Чосич занимался всю жизнь. Добрица Чосич писал свои дневники с 1951 по 2000 г. Это полувековая история страны, в которой историкам, благодаря работам Чосича, теперь будет проще разобраться. Дневники полны искренности, написаны человеком, который себя идентифицировал с эпохой. Поэтому когда вы сегодня пишите о Тито, Сталине, о советско-югославским отношениях, об Александре Ранковиче, Джиласе, студенческих движениях 1968 г., албанском вопросе, политике неприсоединения, распаде Югославии и так далее ... вплоть до агрессии НАТО 1999 г., без работ Добрицы Чосича понять страну и народ вы не сможете. Будучи Президентом Югославии в 1992-1993 гг., Чосич оставил потомкам «Записки президента Союзной Республики Югославии». Его наследие многогранно, а значение его работ для понимании исторических событий современной Эпохи велико. 